\title{
Exploring Phases of Knowledge through Group Work and Online Engagement
}

Siti Aishah Taib, Siti Mariam Mohammad Iliyas, Maisarah Noorezam, Nadzrah Sa'adan, Noor Shahariah Saleh, Norhisyam Jenal

To Link this Article: http://dx.doi.org/10.6007/IJARBSS/v11-i11/11307

DOI:10.6007/IJARBSS/v11-i11/11307

Received: 15 September 2021, Revised: 18 October 2021, Accepted: 30 October 2021

Published Online: 14 November 2021

In-Text Citation: (Taib et al., 2021)

To Cite this Article: Taib, S. A., Iliyas, S. M. M., Noorezam, M., Sa'adan, N., Saleh, N. S., \& Jenal, N. (2021). Exploring Phases of Knowledge through Group Work and Online Engagement. International Journal of Academic Research in Business and Social Sciences, 11(11), $862-881$.

Copyright: (c) 2021 The Author(s)

Published by Human Resource Management Academic Research Society (www.hrmars.com)

This article is published under the Creative Commons Attribution (CC BY 4.0) license. Anyone may reproduce, distribute, translate and create derivative works of this article (for both commercial and non-commercial purposes), subject to full attribution to the original publication and authors. The full terms of this license may be seen

at: http://creativecommons.org/licences/by/4.0/legalcode

Vol. 11, No. 11, 2021, Pg. $862-881$

Full Terms \& Conditions of access and use can be found at http://hrmars.com/index.php/pages/detail/publication-ethics 


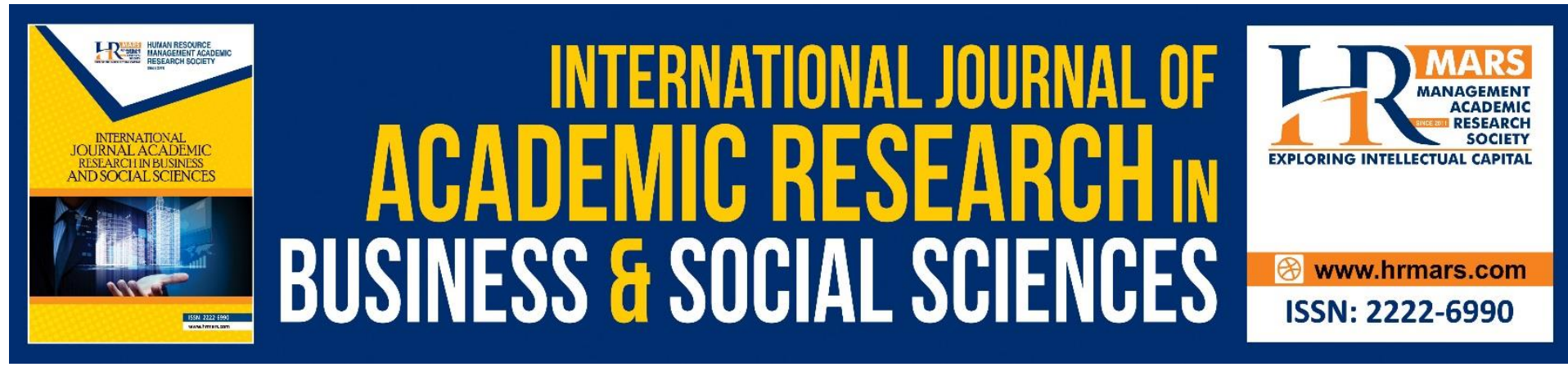

\title{
Exploring Phases of Knowledge through Group Work and Online Engagement
}

\author{
Siti Aishah Taib ${ }^{1}$ Siti Mariam Mohammad Iliyas², Maisarah \\ Noorezam³ ${ }^{3}$, Nadzrah Sa'adan ${ }^{4}$, Noor Shahariah Saleh ${ }^{5}$, \\ Norhisyam Jenal ${ }^{6}$ \\ 1,2,3,4Akademi Pengajian Bahasa, Universiti Teknologi MARA Cawangan Johor, Kampus Pasir \\ Gudang, ${ }^{5}$ Akademi Pengajian Bahasa, Universiti Teknologi MARA Cawangan Negeri \\ Sembilan, Kampus Seremban, ${ }^{6}$ Kolej Pengajian Kejuruteraan, Universiti Teknologi MARA \\ Cawangan Johor, Kampus Pasir Gudang \\ Email: aishah711@uitm.edu.my, sitim364@uitm.edu.my,maisa691@uitm.edu.my, \\ nadzr210@uitm.edu.my, noorshahariah@uitm.edu.my, hisyam0324@uitm.edu.my
}

\begin{abstract}
As a result of the Covid-19 outbreak, educators worldwide have shifted to online instruction. Open and distance learning (ODL) enables lecturers and students to continue learning sessions from the comfort of their own homes with minimal risk of infection. Online collaborative learning $(\mathrm{OCL})$ is gaining popularity in higher education institutions in this regard. However, lecturers must understand how students collaborate with their peers, communicate with their instructors, and engage in collaborative learning projects for online learning to be successful. As a result, it is necessary to better understand student knowledge construction through discourse in group work by examining online group participation. This quantitative study analysed responses to a 36-item questionnaire from 246 respondents enrolled in Malaysian higher education institutions. The findings revealed how idea generating, idea organising, and intellectual convergence in $\mathrm{OCL}$ were portrayed in online group engagement. Implications of the study include evidence and information on knowledge construction in the practice of OCL in ODL during Malaysia's Movement Control Order (MCO). Future research in the practice of $O C L$ is also discussed in this study.
\end{abstract}

Keywords: Online Collaborative Learning (OCL), Open and Distance Learning (ODL), Group Work, Online Engagement, Phases of Knowledge

\section{Introduction}

Background of Study

Online learning, also known as virtual learning, e-learning, and computer-assisted learning, is regarded as a new social process that is beginning to act as a complete substitute for both distance learning and the traditional face-to-face class (Hiltz \& Turoff, 2005). The term can be defined as a computer-based educational tool or system that enables learners to learn anywhere and at any time (Epignosis, 2014). In the perspective of higher education, the term 
can be defined as a range of online practices (Nicholson, 2007). In short, online learning unites two major aspects; learning and technology (Aparicio et al., 2016).

Online learning has taken the world by storm and made more significant by the recent COVID19 pandemic, which has forced changes in many aspects, including the process of teaching and learning. The outbreak has made online learning more significant in people's lives, and its usage has been steadily increasing ever since (Koksal, 2020). It is generally designed in a more appealing and digestible form as compared to traditional learning, whereby a teacher stands in front and delivers information that will presumably be understood and remembered by the students. More accommodating to all learning styles, better flexibility, and appealing to wider audiences are some of the many aspects of how online learning has changed the way teaching and learning are implemented.

In Malaysia, other than the need for transition due to the pandemic and its positive attributes, online learning is also actively expanding as a part of the wider offer of educational services due to the massive development of information and communication technology (ICT). This is also contributed by the demand for education especially among adults as the result of the shift from an industry-based economy to a knowledge-based economy with human capital as the focus of development (Endut et.al., 2012).

\section{Statement of Problem}

Online learning is accepted positively by learners in various aspects, and the acceptance gets better gradually as the implementation takes place (Kamal et.al., 2020). In terms of students' acceptance, generally, students are interested, especially if online learning is implemented with an interactive activity and made familiar with the integration of previous learning experience (Zakariah et. al., 2012). Positive outcomes were also observed in the implementation of online learning via social media (Alias et.al., 2012; Sidek \& Yunos, 2012). On top of that, online learning is also positively accepted with messaging applications such as WhatsApp as the platform of learning support as it is rated significantly high in the aspects of students' perceived usefulness, availability of learning support, motivation, and connectedness with their friends (Mulyono et al., 2021). Virtual teaming is also the aspect valued by the learners despite it also being a challenge in the online learning environment (Kim, Liu, \& Bonk, 2005). On top of that, online learning is also perceived positively as it offers ease of communication and more convenient information sharing (Chew, 2015).

However, online learning does have its own challenges. On the top of the list for the challenges of online learning is technical issues, including unstable or poor internet connections, lack of access to softwares, and incompatible hardwares (Bączek et.al., 2021; Chew, 2015; Tanjung \& Utomo, 2021). Similar to the challenge as in the conventional way of teaching and learning, Liang and Chen (2012) highlight the aspect of whether the teaching approach in online learning suits the style of preference of different learners. Some students also perceived online learning as difficult and boring hence being less active in the online session as compared to the conventional face-to-face class (Bączek et.al., 2021; Chew, 2015). Furthermore, inconsistency of assessment implementation such as the platform used and scheduling also leads to learners' frustration (Tanjung \& Utomo, 2021). In addition, lack of training for successful group communication in an online setting as well as the different environment of interaction itself as compared to face-to-face group work setting do 
contribute to the setback of its implementation (Brindley, Blaschke, \& Walti, 2009). Hence, this study is done to investigate how online learning influences engagement.

\section{Objective and Research Questions}

Generally, this study is done to explore the acquisition of different phases of knowledge through online engagement. This study is done to:

- $\quad$ explore how students generate ideas in online group engagement

- $\quad$ explore how students organise ideas in online group engagement

- $\quad$ explore how students participate in intellectual convergence in online group engagement.

Specifically, this study is done to answer the following questions:

How is idea generation portrayed in online group engagement?

How is idea organising portrayed in online group engagement?

How is intellectual convergence portrayed in online group engagement?

\section{Literature Review}

Introduction

This section discusses factors that influence online learning, past studies and also the conceptual framework of the study.

\section{Online Collaborative Learning}

Online learning facilitates learning in several phases. According to Barabasi (2002), there are three phases in online collaborative learning $(\mathrm{OCL})$. The first phase is the idea generating phase. This is the brainstorming phase. This is the phase where divergent ideas are gathered. The second phase is the idea organising phase. This is the phase where ideas are compared. They are analysed and also categorised this phase involves discussion and even arguments. Finally, the last stage is the intellectual convergence phase. This is the phase where learners synthesise ideas and arrive at a consensus. This phase includes agreeing to disagree, usually through an assignment, essay, or other joint pieces of work.

\section{Group Collaboration in the Online Class}

There are some reports to show that group work via online can bring both advantages and disadvantages. In relation to the Theory of Planned Behaviour, Cheng and Chu (2015) found that students' past experience and behaviour positively influence their subjective norms, attitudes, and perceived behavioural control of collaborating online, which positively affect their intentions to collaborate for group projects. Besides, online discussions as part of group collaboration help in promoting depth understanding of a topic in terms of expressing thoughts, rethinking values, and applying learned material to new issues (Hamann et al., 2012). However, Robinson (2013) in his study that resonates with the sociocognitive model of self-regulated learning, mentioned that, unlike face-to-face classrooms where students' emotions can easily be seen, group collaboration in the online environment needs to be more detailed and overt textually to communicate emotions. According to Artino and Jones (2012), due to technical issues and the social isolation of attending classes online, online learning environments may contribute to negative achievement-related emotions such as anxiety and 
frustration. In addition, social loafing can be detrimental when working collectively. Messersmith (2015) noted that online group work aggravates social loafing, due to the inequality of members' efforts. These studies, among the numerous researches, indicate the ambivalence about group collaboration in the online classroom setting.

\section{Past Studies}

\section{Past Studies on Group Work}

Several studies have been conducted on the advantages and disadvantages of group work. Costly (2021) examined survey responses from 1399 university students in South Korea who participated in collaborative study groups while attending online classes. It was revealed that a student's level of cooperation had a beneficial impact on their germane load. It was also discovered that students who contributed less to the group benefited more from higher levels of collaboration than students who took a more active part.

Meanwhile, Roskosa and Rupniece (2016) conducted a study on 56 students from Riga University's Institute of Applied Linguistics to determine the benefits and downsides of group work in translation education. The data collected were based on the content analysis done on the students' essay on "The Use of Group Work in the Process of Translation" The study's findings demonstrate that employing group work in the translation process offers several major benefits, including the ease with which ideas, opinions, knowledge, and experience may be shared, increased translation quality, and a faster translation process. Students also believe that when they work as a group, the environment is more positive and encouraging. However, according to Roskosa and Rupniece (2016), students have noted a variety of drawbacks to group work, including disputes that cause attention issues and lower work capacity. Another drawback of group labour is that it diminishes the accountability of group members because not everyone's engagement, activity, and performance are equal. A drawback of group work is that work progress speeds vary as some of the group members translate too fast or too slowly. According to the content analysis done, students were also unable to work freely and at their own pace. The absence of expertise was viewed as a drawback of group works and students emphasised how the views of their peers may influence them, causing them to lose their ideas, inventiveness, and make mistakes.

LaBeouf, Griffith, and Roberts (2016) examined 811 respondents' remarks to find out how they felt about group work in the classroom. The most significant concern raised by both groups was the distribution of grades among group members. Students believed that in a group assignment, regardless of work, all students earned the same grade, which they said was not equitable. Students also reported challenges they have while working on group assignments in online or distance learning environments, citing restricted engagement, time zone variations, and varied work schedules as obstacles to effective collaboration.

Meanwhile, based on interviews with 19 professors and 23 students from various disciplines at a pre-service teacher education department at a university in Vietnam, Le, Janssen, and Wubbels (2018) discovered that there are four frequent hurdles to collaboration: students' lack of collaborative abilities, free-riding, competence status, and friendship.

\section{Past Studies on Group Work Online}

Many studies have examined collaborative learning concerning online implementation, focusing on the advantages and challenges. Trang et al. (2021) carried out research to determine the merits and drawbacks of online group learning for EFL students at Van Lang University (VLU). The study included $60 \mathrm{EFL}$ students ranging from first-year to fourth-year 
English majors and was drawn from several batches. Using Google Form, an online survey with 10 basic closed questions was used. The researchers pointed out that the respondents benefited from online collaborative learning as it saved money and time, enabled discussions to take place regardless of time or location, made meetings simple and allowed performance monitoring and developing team skills. Despite these benefits, the research found that most students preferred face-to-face collaboration and stated that online problem solving was difficult. The analysis revealed that students encountered a distracting atmosphere and felt frustrated and irritated, although the learning was stimulating. Delays in replies, coping with inactive teammates, technical difficulties, communication breakdowns, evaluation difficulties, being harsh on non-tech savvy members and plagiarism were all obstacles that the students had to overcome. The results gave educators insight into creating more successful educational activities and how to help learners during online group learning.

Kumi-Yeboah et al. (2017) investigated the benefits and drawbacks of online group work in the setting of cultural diversity. They also looked at learners' preferences in such contexts. The researchers used a qualitative research design and conducted semi-structured interviews, focus groups, and observations. Twenty full-time graduate students from culturally diverse backgrounds enrolled in Master's degree programmes in Instructional Technology, and Special Education at Northeastern United States universities participated in the study. Not only were online collaborative learning activities seen to enhance knowledge creation and construction, but they were also judged to be more effective when conducted in small groups. Additionally, online activities, including group work, provided chances for sharing and leading debate rather than promoting academic success. However, despite the positive response, participants had difficulty navigating cultural differences and stated that the curriculum and online reading material lacked a multicultural perspective. Thus, there was a need to understand better minority graduate students' attitudes toward online collaborative learning. Therefore, the research emphasised the significance of cultural diversity while implementing online joint learning activities and methods and enabling different graduate students in the classroom.

Studies exploring the difficulties associated with online group interaction reveal components that impede the process of effective collaboration. For example, Muuro et al. (2014) performed an analysis based on the Constructive theory that included 210 students from four institutions in Nairobi, Kenya, enrolled in at least one course or module online through an elearning platform. The pupils that were sampled did so voluntarily and answered a questionnaire. The study discovered that the components perceived as challenging were a lack of member participation, a lack of participation time, differences in skill and proficiency levels, slow network access, peer disruptions, a lack of precision, free riders, disagreements during the discussion, and issues with idea authenticity. The study indicated the need for further large-scale research and advocated for improvements in implementing online group interaction activities and tools.

Similar to Muuro et al (2014); Omodan and Ige's study (2021) sought to determine the factors contributing to online group work's ineffectiveness among undergraduate students. The researchers structured their study around Ubuntu, an African philosophy that applies the concept of humanity, unity, and social morality in determining an individual's productive success. As a consequence of the COVID-19 epidemic, a reassessment of the employment of an online classroom community project was necessary. Therefore, the study adopted a qualitative research method grounded on a transformative paradigm and a participatory research design. The sample consisted of 810 first-year university students who participated 
in a specific curriculum at a chosen institution in South Africa and were subsequently divided into ten groups for online community projects. The ten group leaders were invited to join a WhatsApp group to discuss the difficulties they encountered before, during, and after the online collaborative learning. The research revealed that student participants had problems locating group members, unstable internet connections, and power outages. In overcoming the obstacles, participants were advised to foster tolerance among group members and to continuously engage in online community initiatives to cope with the new COVID-19 standards. Alternatively, the research recommended the use of the Ubuntu concept for managing group activities.

Conceptual Framework

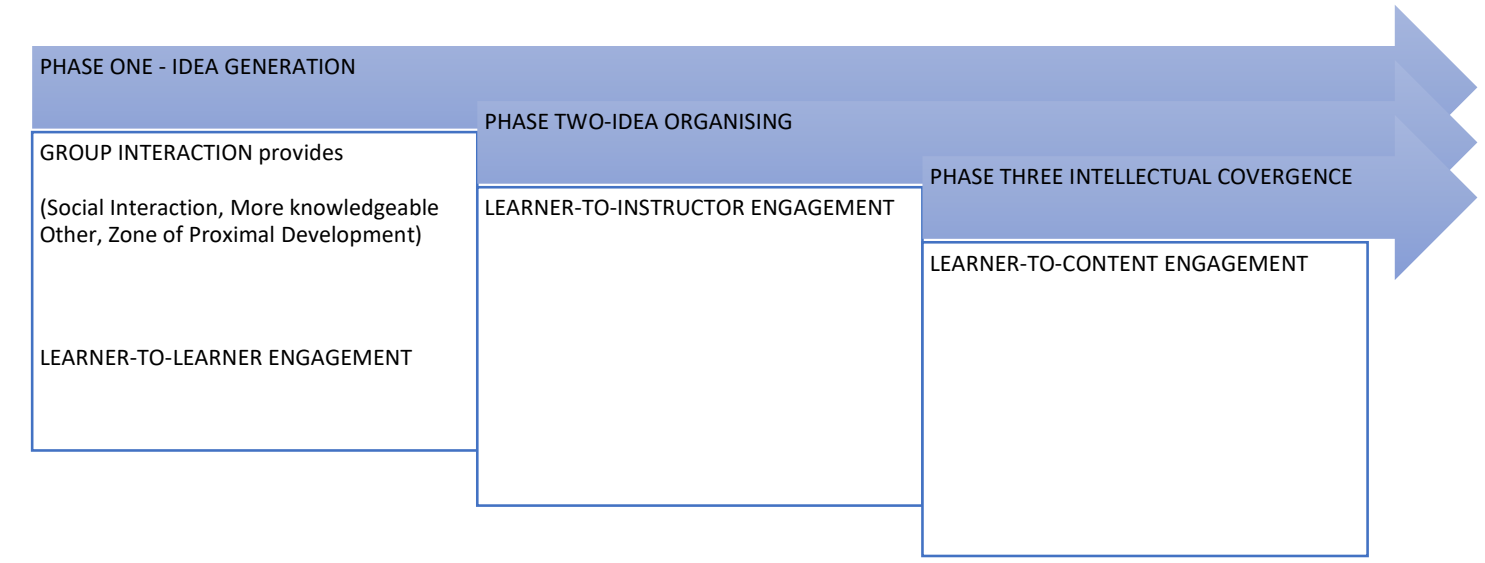

Figure 1- Conceptual Framework of the Study

(Source: Barabasi, 2002 and Martin \& Bollinger, 2018)

This study (figure 1) is rooted in the three phases of online learning by Barabasi (2002). The three phases are then scaffolded onto the three types of online engagement by Martin and Bollinger (2018). Idea generation is done through learner-to-learner engagement. Next, Idea organising is done through learner-to-instructor engagement. Finally, intellectual convergence is done through learner-to-content engagement.

\section{Methodology}

This quantitative study is done to explore online engagement through three phases of knowledge generation. 246 students from a public university responded to the instruments (table 1). The instrument is a survey with four sections. Section A is the demographic profile. Section B has 16 items on idea generation. Section $C$ has 6 items on idea organising while section $D$ has 7 items on intellectual convergence. 
Table 1-Distribution of Items in Instrument

\begin{tabular}{|l|l|l|l|}
\hline SECTION & \multicolumn{2}{|l|}{} & $\begin{array}{l}\text { No of } \\
\text { Items }\end{array}$ \\
\hline A & \multicolumn{2}{|l|}{ Demographic Profile } & 2 \\
\hline B & IDEA GENERATION & Social Interaction & 6 \\
\hline & & MKO & 5 \\
\hline & & ZPD & 5 \\
\hline C & $\begin{array}{l}\text { Learner-to-Learner } \\
\text { Engagement }\end{array}$ & 6 \\
\hline D & IDEA ORGANISING & $\begin{array}{l}\text { Learner-to-Instructor } \\
\text { Engagement }\end{array}$ & 7 \\
\hline & INTELLECTUAL & $\begin{array}{l}\text { Learner-to-Content } \\
\text { Engagement }\end{array}$ & 7 \\
\hline & CONVERGENCE & & 36 \\
\hline
\end{tabular}

Table 2-Reliability Statistics

\section{Reliability Statistics}

\begin{tabular}{r|r}
$\begin{array}{c}\text { Cronbach's } \\
\text { Alpha }\end{array}$ & N of Items \\
\hline .966 & 36 \\
\hline
\end{tabular}

Table 2 shows the reliability statistics for the instrument (Cronbach alpha of . 966), thus showing a high internal reliability of the instrument.

\section{Findings}

Introduction

This section presents the findings of this study. The first section presents the findings for the demographic profiles in terms of percentages. The other sections present the findings for the research questions in terms of mean scores.

\section{Findings for Demographic Profile}

\section{Gender}

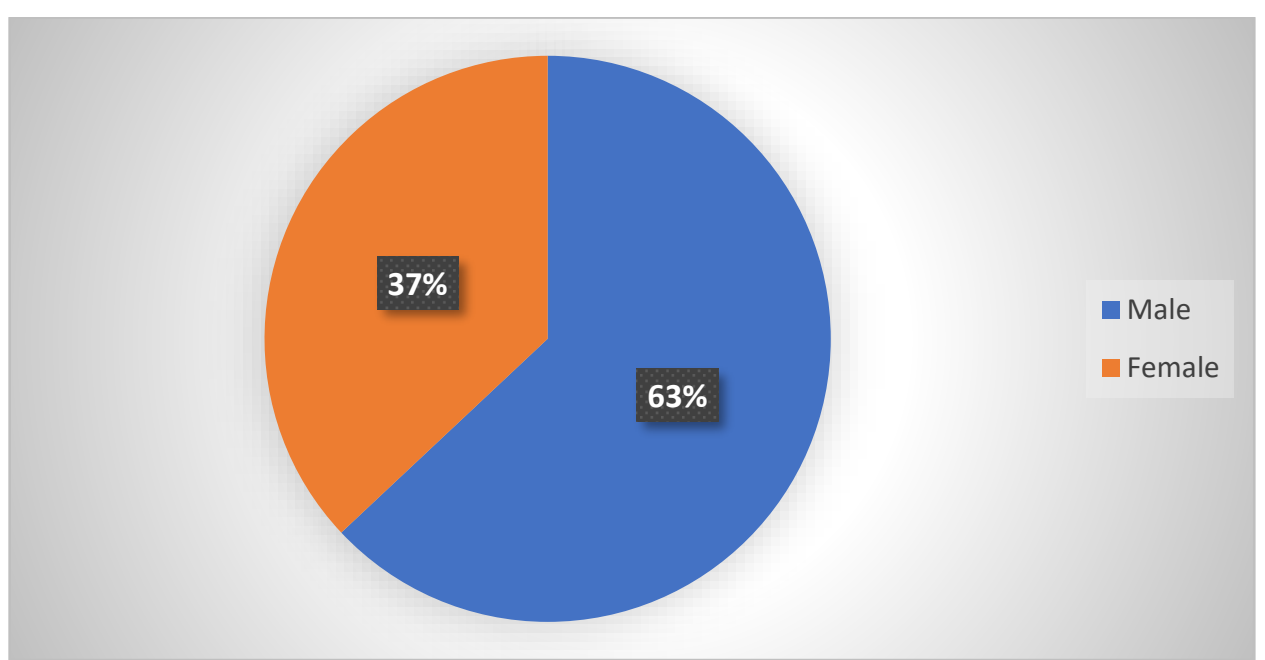

Figure 2- Percentage for Gender 
A total of 246 respondents were included in the sample (figure 2). Males made up the vast majority of student responses (63\%) compared to females (37\%).

Age Group

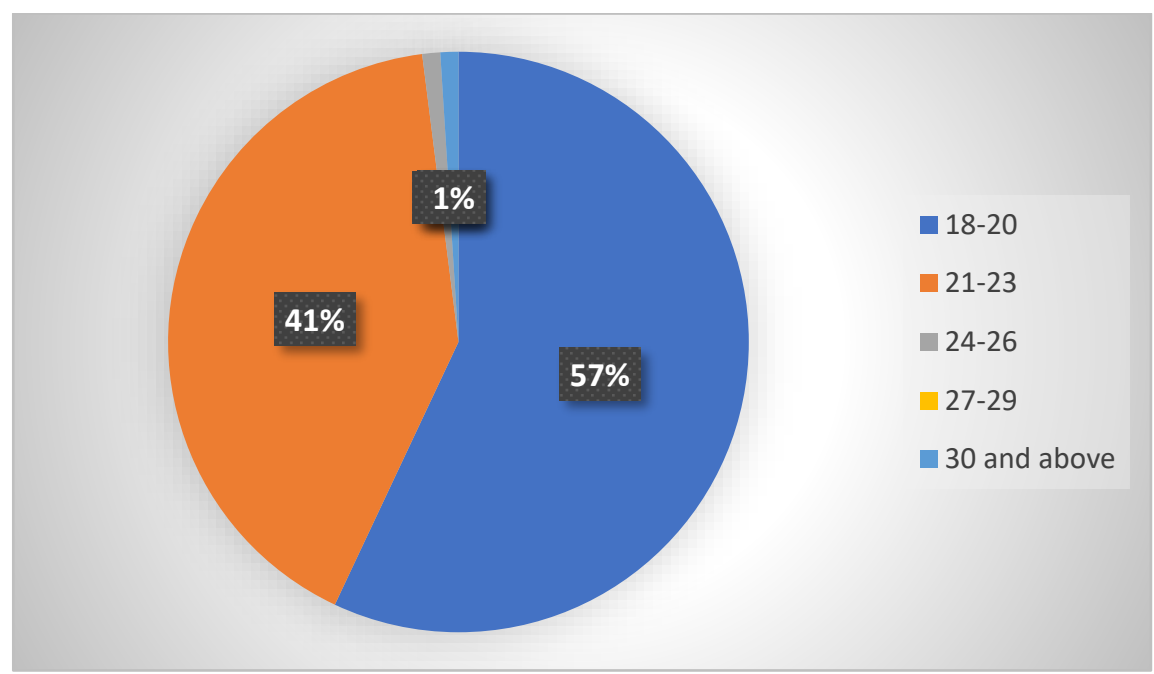

Figure 3- Percentage for Age Group

The study's respondents were classified into five distinct age groups ranging from 18 to over 30 years old. According to Figure 3, most respondents (57\%) were between the ages of 18 and 20 , followed by $41 \%$ between the ages of 21 and 23 . Meanwhile, just $1 \%$ of responses were in the age categories of 24 to 26 and 30 and above. There was no response from the group of individuals aged 27 to 29 .

Current Study

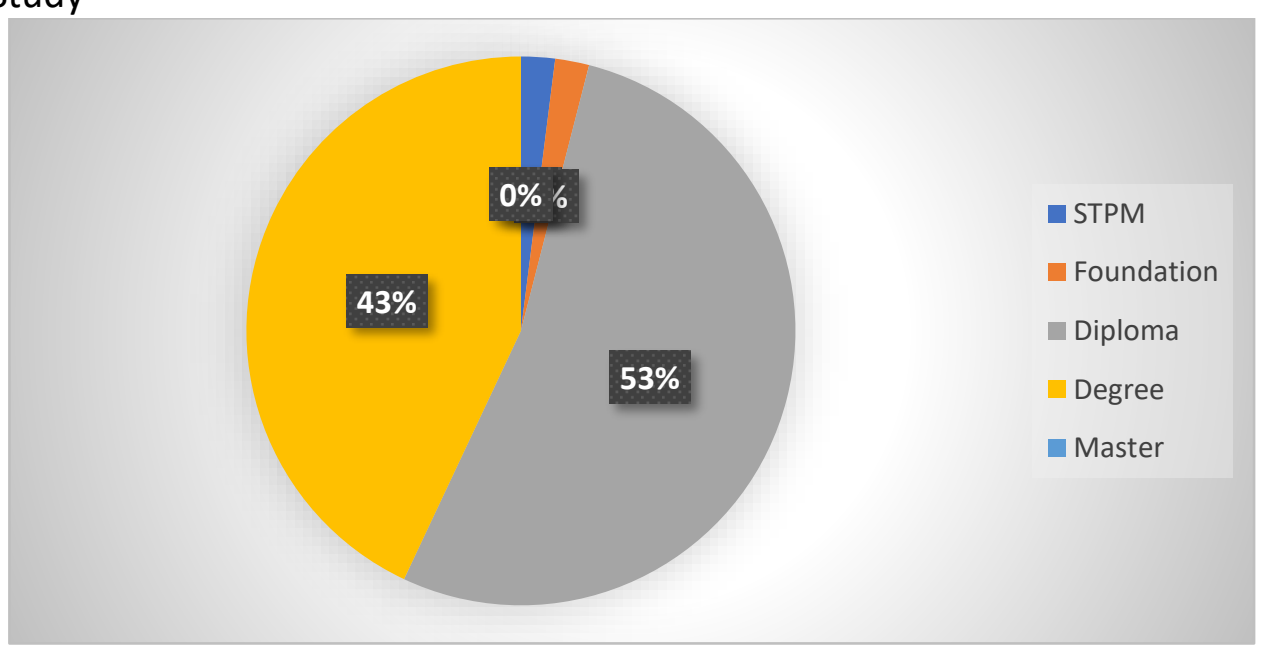

Figure 4- Percentage for Current Study

Figure 4 reveals that more than half of respondents were diploma students (53\%). In the meantime, $43 \%$ of the respondents were enrolled in degree programmes. Respondents with STPM and foundation current study backgrounds took part in this research at a rate of $2 \%$, whereas students with a Master's degree did not participate. 
Semester

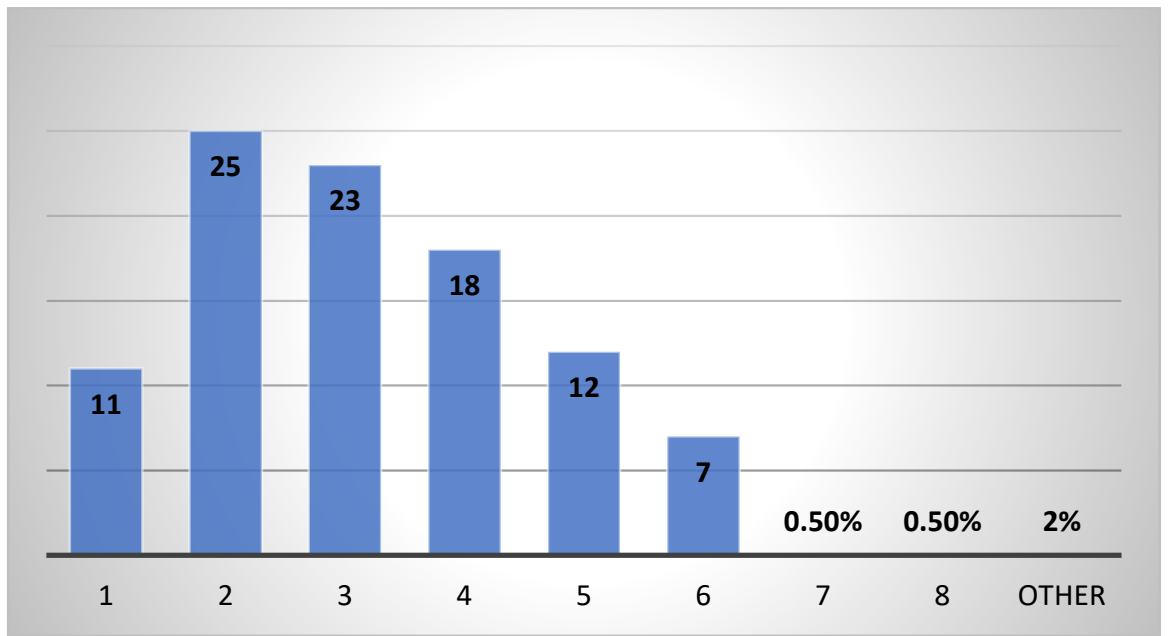

Figure 5- Percentage for Semester

The semesters of study in which the respondents were involved during the research are shown in Figure 5 . One-quarter of respondents (25\%) were in their second semester, closely followed by those in their third semester (23\%). Respondents in their fifth and first semesters were tallied at a rate of $13 \%$ and $11 \%$, respectively. Less than $10 \%$ of respondents in this research were in sixth $(7 \%)$ or other semesters $(2 \%)$. Thus, just a tiny proportion of participants came from semesters 7 and 8 , accounting for less than $0.5 \%$ of total participation.

Previous Semester

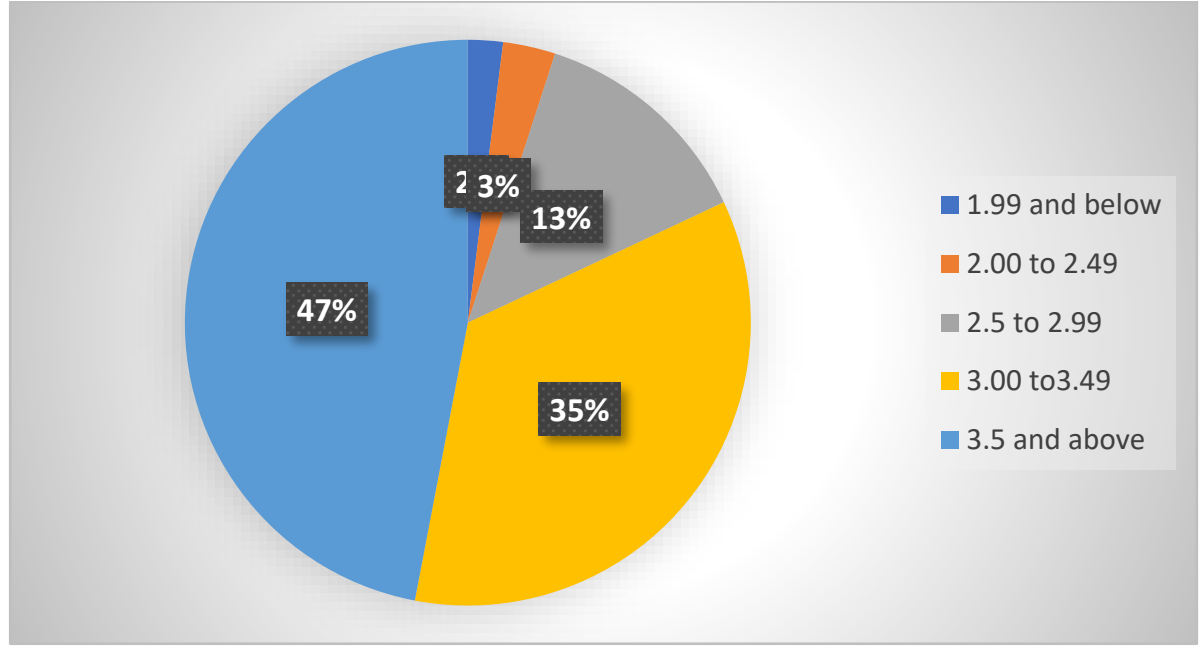

Figure 6- Percentage for Previous Semester

Figure 6 above presents the proportion of the prior semester CGPA of respondents. The figure indicates that most of the respondents earned a CGPA of 3.5 and above for the previous semester. With $35 \%$, those who scored between 3.00 and 3.49 are next. $13 \%$ of students obtained a CGPA ranging from 2.5 to 2.99 . There were $5 \%$ of respondents who received a score of less than 2.5; $3 \%$ of respondents scored 2.0 to 2.49 , while $2 \%$ had a 1.99 and below. 
Type of University

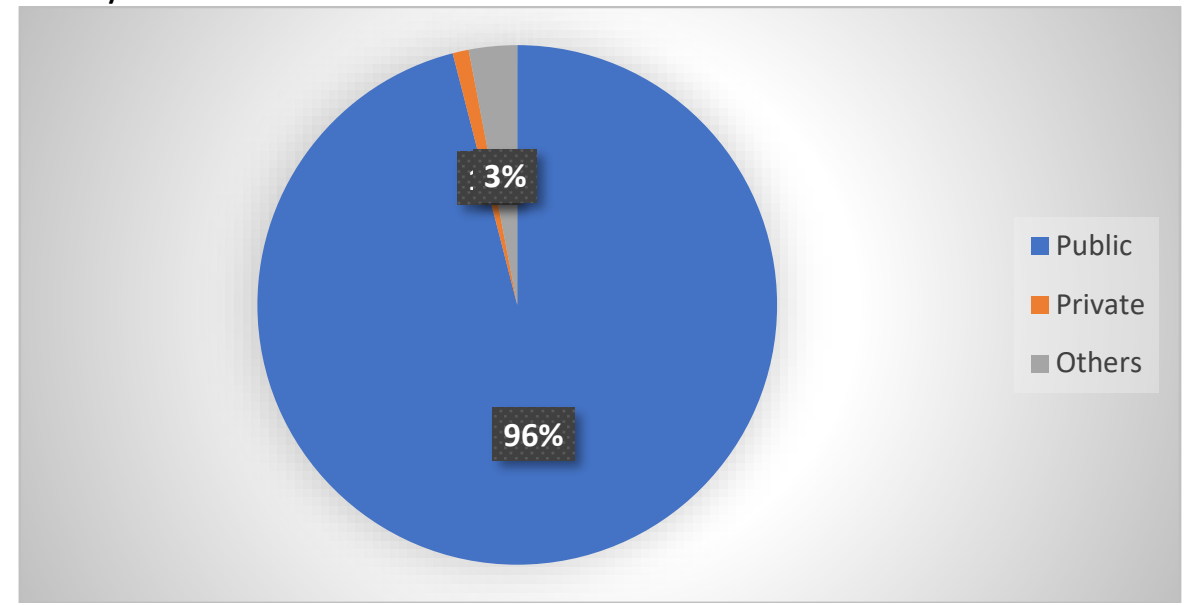

Figure 7- Percentage for University

As shown in Figure 7 above, the vast majority of the survey respondents were from public universities (96\%). Only 3\% of respondents selected 'others,' while the remaining $1 \%$ identified private higher institutions as the type of university they attended.

Face-to-face Class Experience

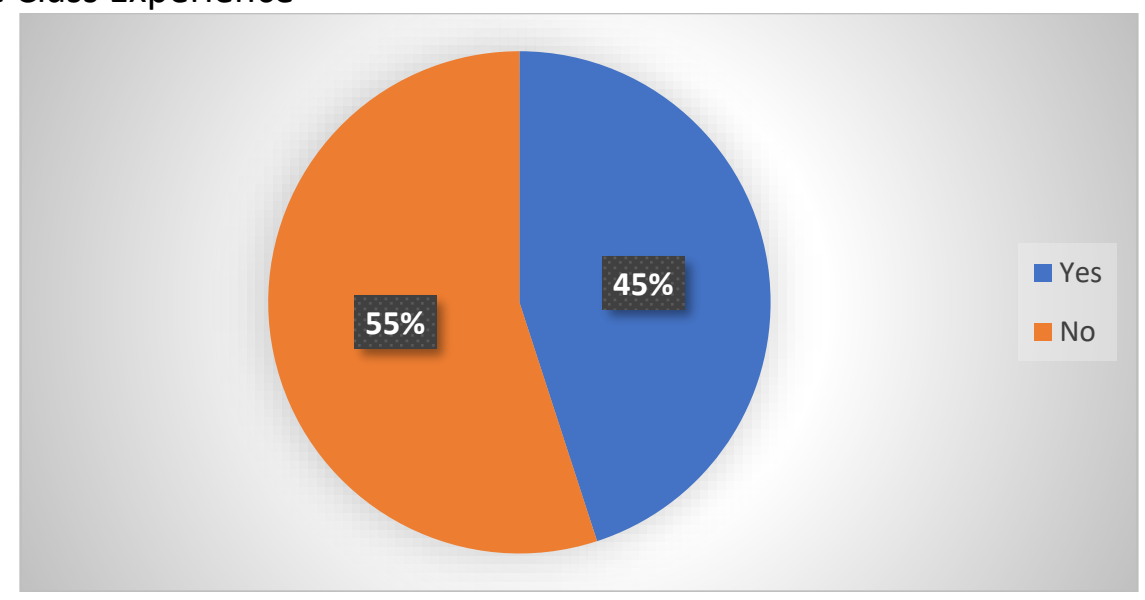

Figure 8- Percentage for Face-to-face Experience

Figure 8 depicts information on the experience with the face-to-face class. More than half of those polled (55\%) claimed that they had never attended a face-to-face lesson. On the other hand, $45 \%$ of the participants agreed that they had the experience of being in an actual class.

\section{Findings for Idea Generation}

This section presents findings to answer research question 1: How is idea generation portrayed in online group engagement? Idea generation is portrayed through (a) Group Collaboration and (b) Learner-to-learner Engagement.

\section{(a) Group Collaboration}

Group collaboration encourages (i) social interaction, learning from (ii) more knowledgeable other and also reduces (iii) zone of proximal development. 
(i) Social Interaction

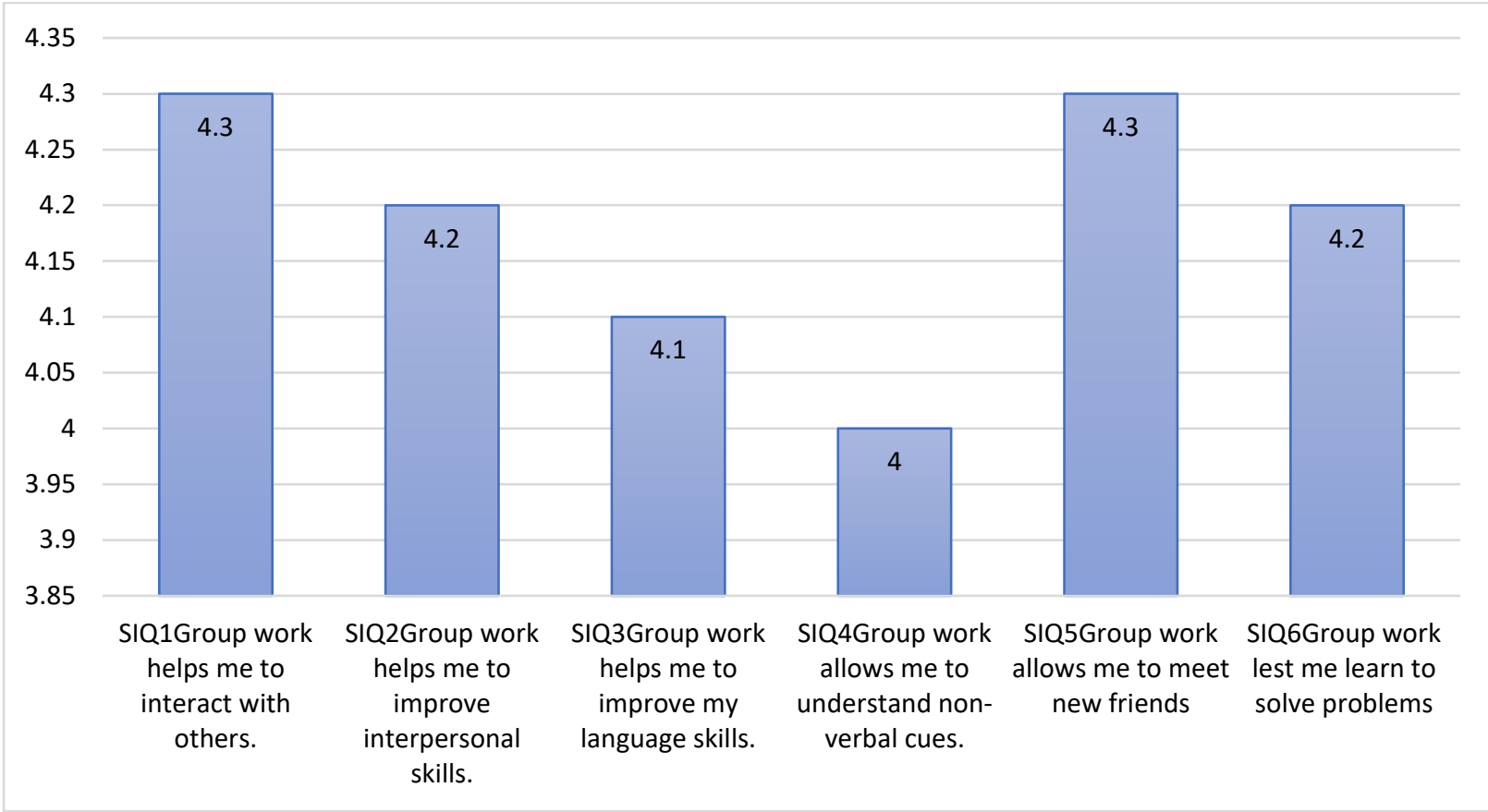

Figure 9-Mean for Social Interaction

The mean values (figure 9) for social interaction in Section $C$ of the survey are depicted in Figure 9. The figure's highest mean is 4.3 , indicating that the respondents agreed that group work helped them interact with others and allowed them to meet new friends. Meanwhile, for two other statements, group work helped the students to improve interpersonal skills and let them learn to solve problems, each statement had a mean value of 4.2. The respondents also agreed with a mean value of 4.1 that group work improved their language skills. The lowest mean for this section is 4 , showing that the students were positive that group work allowed them to understand non-verbal cues.

\section{(ii) MORE KNOWLEDGEABLE OTHER}

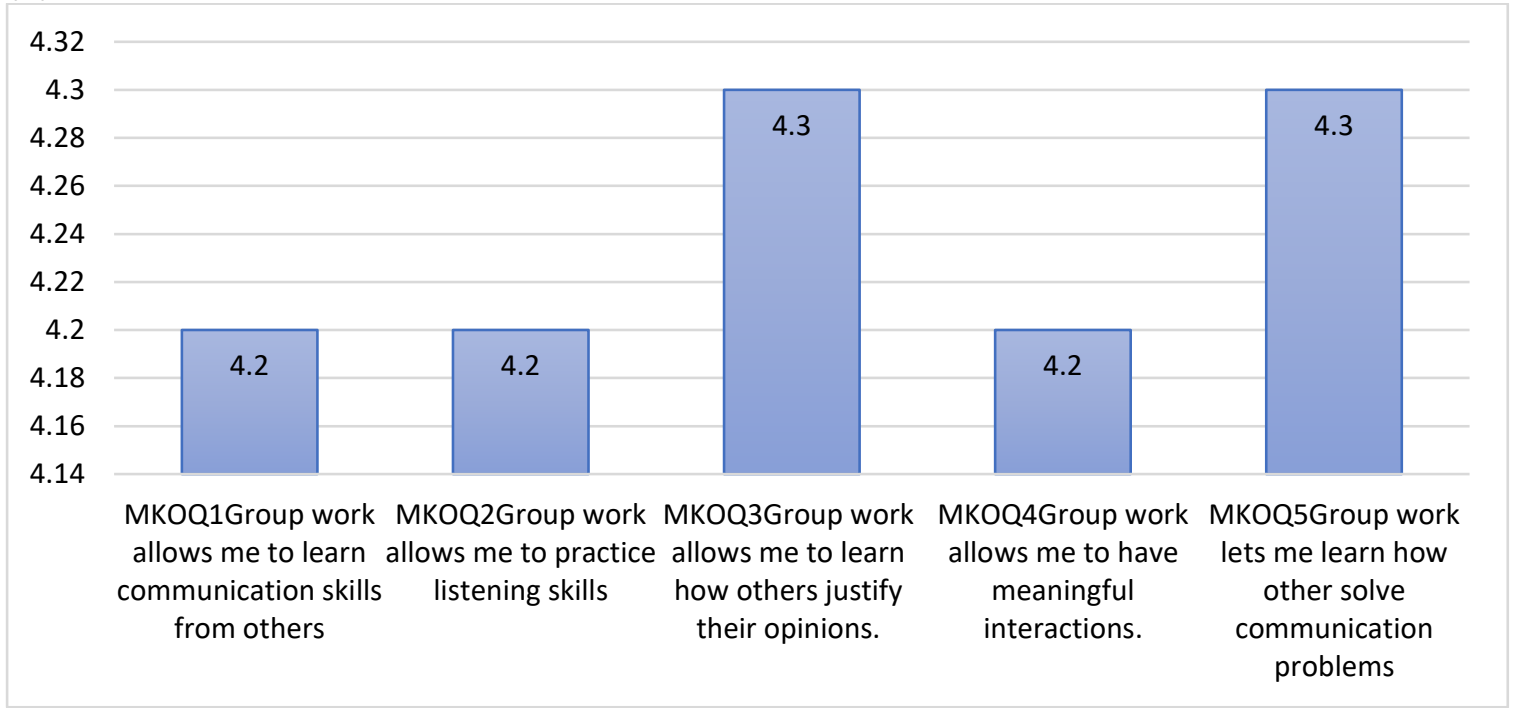

Figure 10-Mean for More Knowledgeable Other 
Figure 10 shows the mean values for more knowledgeable other in Section D of the survey. It shows a significant positive agreement by the respondents on all statements asked in the questionnaire since the value of the mean for each item is higher than 4 . For example, group work allowed the students to learn how others justify their opinions and how others solve communication problems were two statements that achieved the highest mean value of 4.3. Meanwhile, the other three statements, which relate to learning communication skills from others, practising listening skills, and having meaningful interactions, shared the same mean value of 4.2 .

\section{(iii) ZONE OF PROXIMAL DEVELOPMENT}

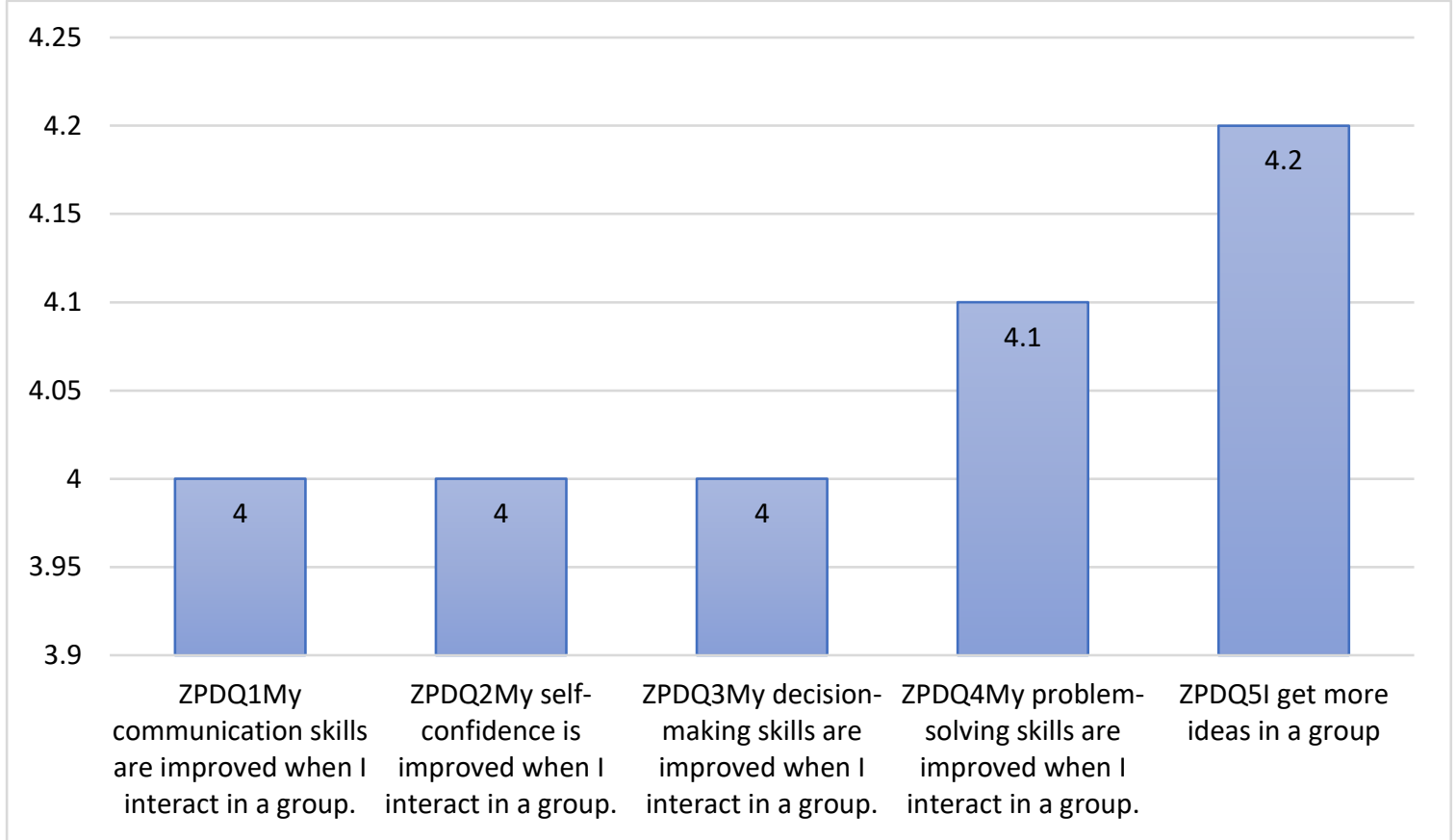

Figure 11- Mean for Zone of Proximal Development

Figure 11 presents the mean for Zone of Proximal Development (ZPD). The highest mean score recorded is 4.2 for 'I get more ideas in a group', followed by 4.1 for 'My problem-solving skills are improved when I interact in a group', and 4.0 for the other three statements, focusing on improved communication skills, self-confidence, and decision-making skills when interacting in a group. In general, the respondents agreed that group interaction does help them to improve many aspects of their learning. 
(b) Learner-to-learner Interaction

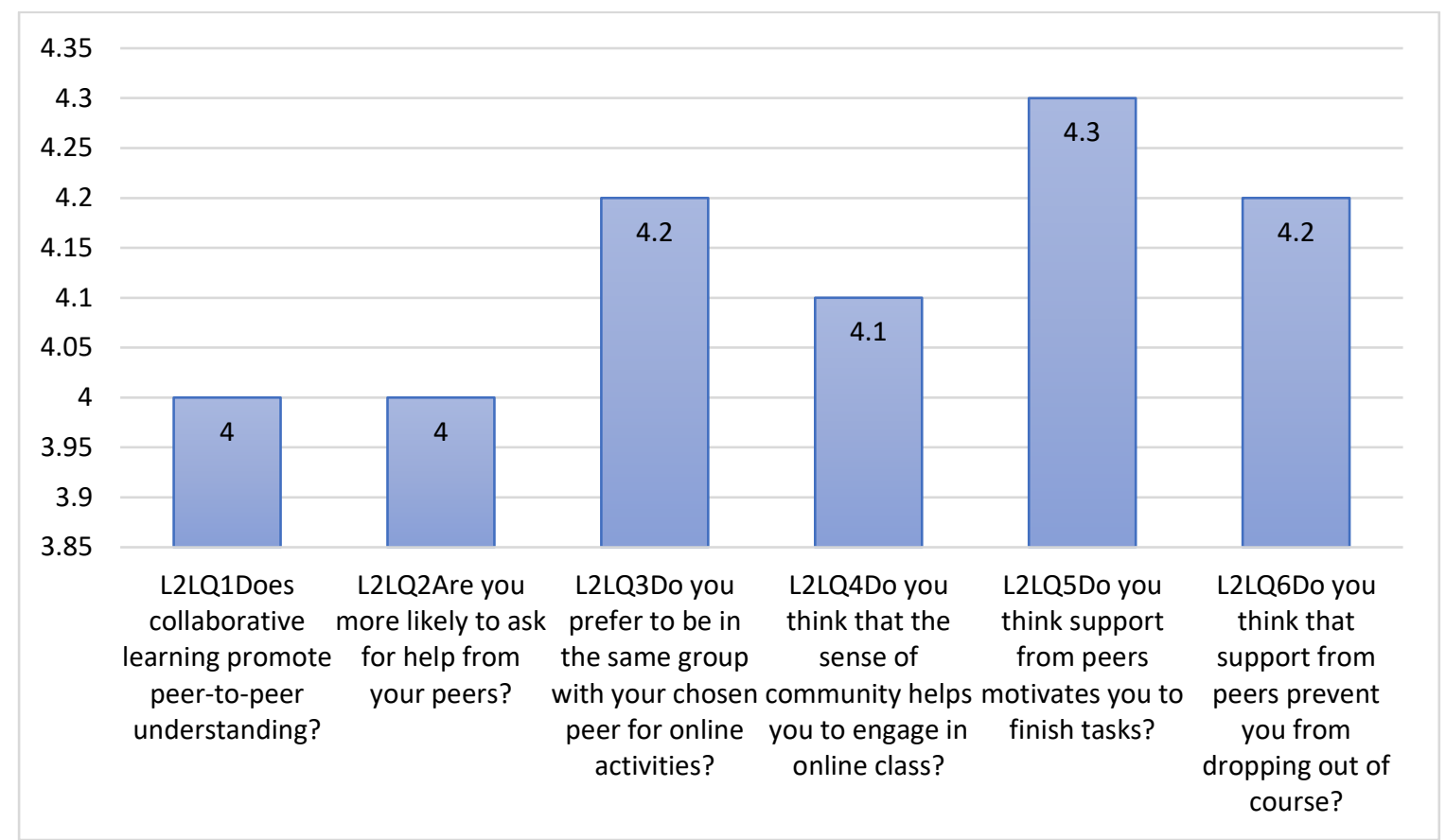

Figure 12-Mean for Learner-to-learner Interaction

Mean scores for learner-to-learner interaction is presented in Figure 12. The highest mean score is recorded for 'peers motivation' at 4.3, followed by 'same group preference' and 'support from peers' at 4.2. The mean score for 'sense of community' is 4.1, and the lowest mean score is 4.0 for both 'peer to peer understanding' and 'asking help from peers'. The responses vary for different aspects with only slight differences, but in terms of agreement, all aspects scored high mean scores which indicate that the respondents generally have good learner-to-learner interactions.

\section{Findings for Idea Organising}

This section presents findings to answer research question 2: How is idea organising portrayed in online group engagement? Idea organising is done through learner-to-instruction interaction. 


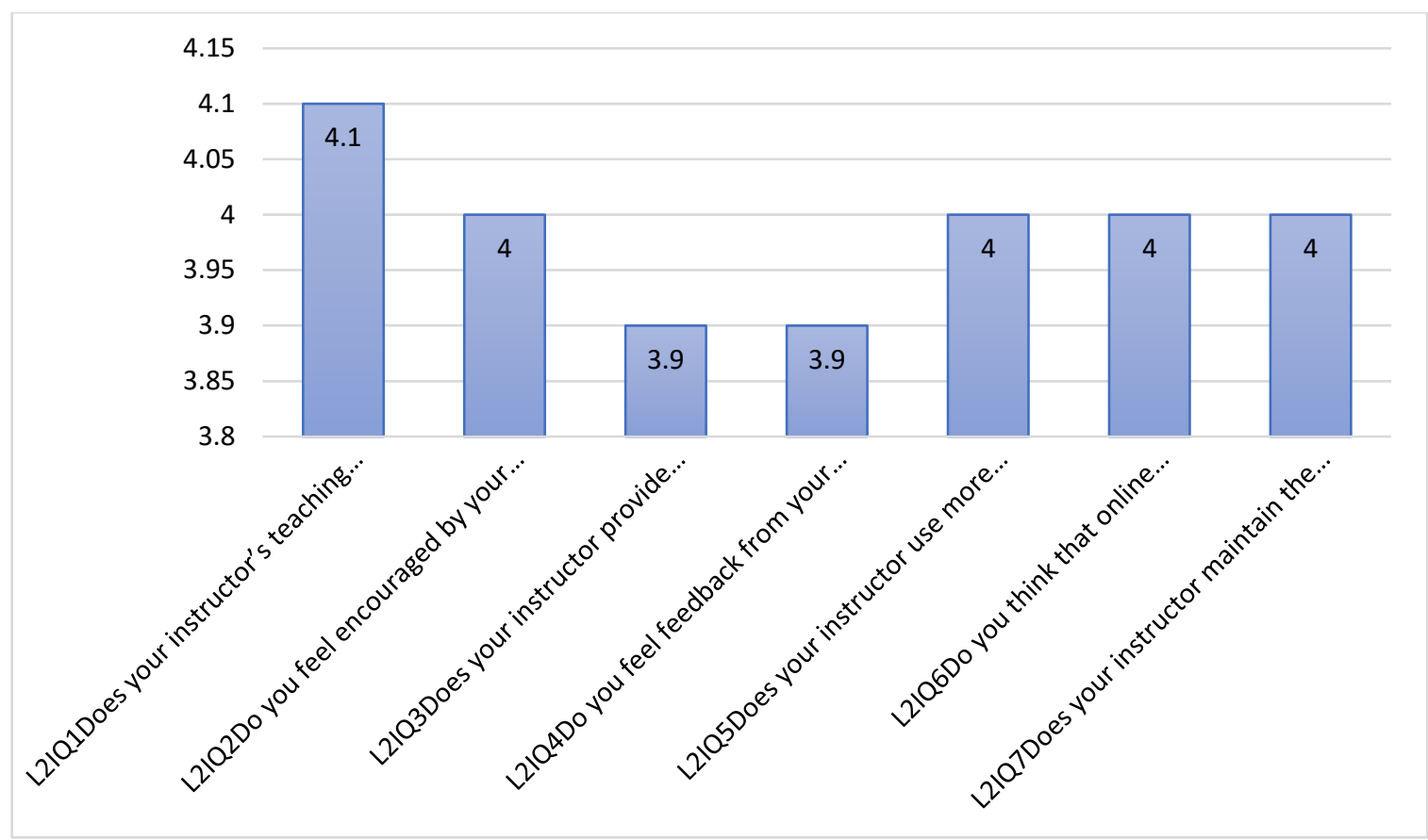

Figure 13-Mean for Learner-to-Instructor Interaction

Figure 13 displays mean data for survey items that measure learner-to-instructor interaction. As noted, the distribution of scores shows only a slightly different mean reading. The highest mean score by 4.1 indicates that students agreed that their instructor allowed students' involvement and active participation in their online classroom. Students also gave positive responses, with 4 mean scores to all four following statements; 1 . they feel encouraged by their instructor to keep engaged in an online classroom, 2. their instructor used more than two communication tools to stay connected with them, 3 . the online platforms used by their instructor are effective and convenient, and 4. their instructor managed to maintain the ongoing interaction with them after online class. Another two remaining items in the questionnaire with a 3.9 mean score each also show the positive engagement between learner and instructor in the online classroom. Students acknowledged that their instructor checked their previous assessment and provided clear and positive feedback too.

\section{Findings for Intellectual Convergence}

This section presents answers to answer research question 3: How is intellectual convergence portrayed in online group engagement? Intellectual convergence is achieved through learnerto-content interaction. 


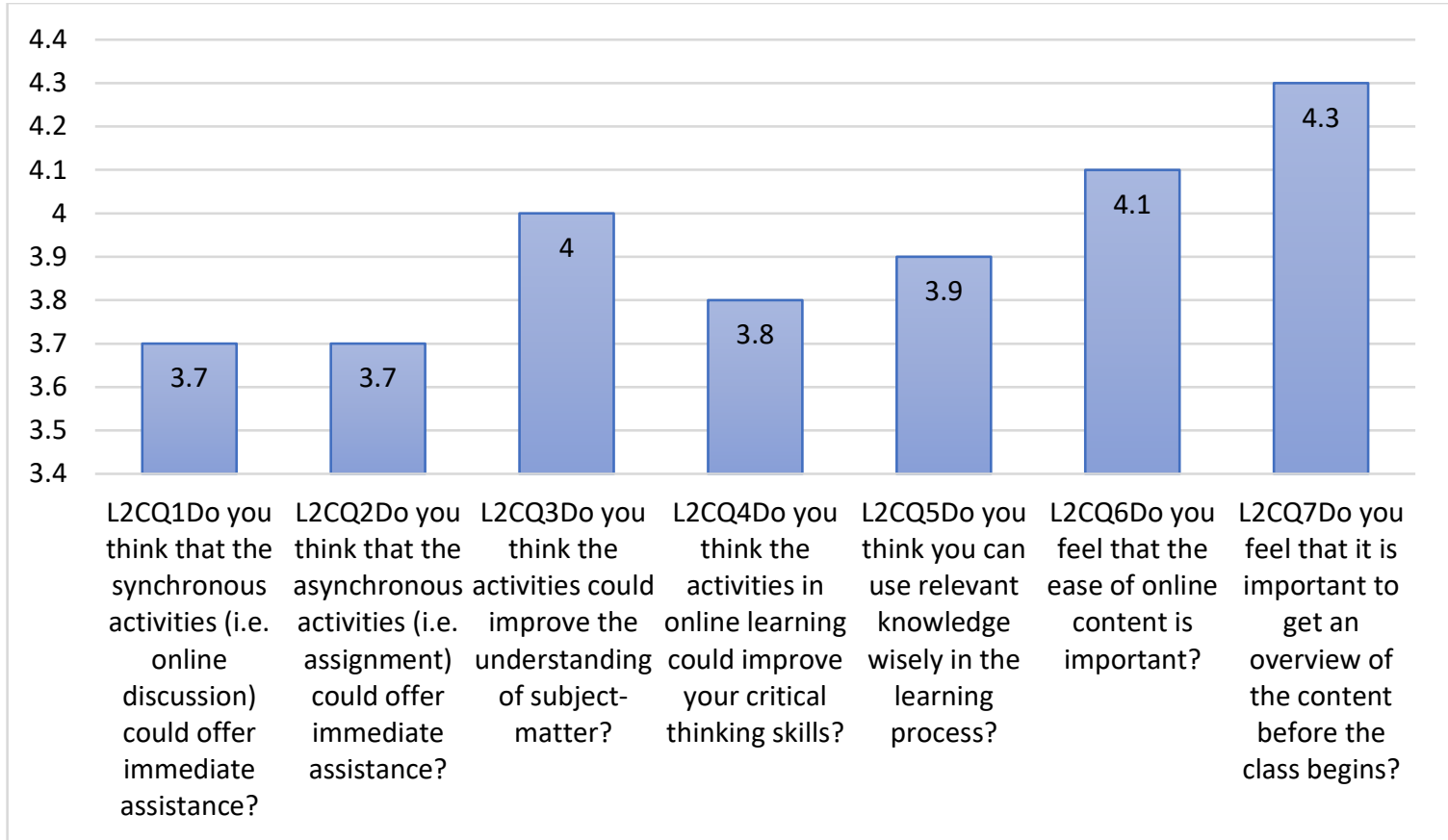

Figure 14-Mean for Learner-to-Content

Figure 14 displays the mean score obtained on the learner to content interaction in answering the third research question: How is intellectual convergence portrayed in online group engagement. It was found that item L2CQ7 recorded the highest mean $(M=4.3)$ that indicates most of the participants agree that it is important to get an overview of the content before the class begins. The second-highest recorded mean is on item L2CQ6 ( $M=4.1)$ that indicates most of the respondents agree that the ease of online content is important.

However, the lowest mean ( $M=3.7)$ is recorded on items L2CQ1 and L2CQ2.

The students agree that the synchronous activities (i.e. online discussion) could offer immediate assistance and it also could offer immediate assistance.

\section{Conclusion}

\section{Summary of Findings and Discussion}

This paper presents how idea generating, idea organising, and intellectual convergence in $\mathrm{OCL}$ were portrayed in online group engagement during ODL by students of higher education institutions. In response to the study's first research question, the findings indicated that respondents reacted positively towards improvement in social interaction, learning from their more knowledgeable counterparts in the group, improvement in several different skills, and learner-to-learner interaction. These findings corroborate prior research on $\mathrm{OCL}$, in which students reported ease of communication in online learning (Chew, 2015), as well as a positive learning environment (Roskosa \& Rupniece, 2016). However, these findings are quite contrary to those shown in previous studies whereby the students expressed concerns about the difficulty in online problem solving (Trang et al., 2021), communication problems (Trang et al., 2021; Brindley et al., 2009), losing ideas (Roskosa \& Rupniece, 2016), idea authenticity and peer disruptions (Muuro et al., 2014).

Meanwhile, the idea organising phase in $\mathrm{OCL}$ was portrayed in online group engagement through learner-to-instructor interaction for the second research question. In this regard, the respondents gave positive answers on their instructor's teaching style, communication tools 
and online platforms, and feedback on their previous assessment and performances. Although students collaborate with their classmates in $\mathrm{OCL}$, it is critical for instructors to be actively involved in the learning process (Martin \& Bolliger, 2018). This active role is demonstrated by recent research, whereby the absence of expertise was viewed as a drawback of group works (Roskosa \& Rupniece, 2016) and feedback deliverance using various modalities by the instructor was sought after by the students (Rahmat et al., 2021).

Lastly, the intellectual convergence phase was portrayed in online group engagement through learner-to-content interaction for the third research question. Additionally, the respondents reacted positively towards content-overview before the class, ease of online content, improvement of subject-matter understanding, critical thinking skills, and immediate assistance from synchronous and asynchronous activities. These findings support previous research whereby OCL promoted depth understanding of subject matter (Hamann et al., 2012) and enhanced knowledge creation and construction (Kumi-Yeboah et al., 2017). Nevertheless, a detailed and overt online environment to communicate emotions (Robinson, 2013) and assignment of small groups (Kumi-Yeboah et al., 2017) must be observed in OCL to improve its effectiveness.

This study gained its roots from the environment of online learning (Figure 1). The interaction during online learning is supported by the theory of online engagement by Martin and Bolliger (2018). Interestingly, group work is added into the online learning environment to reveal how group interactions boost the generation of ideas at different phases. The first phase is idea generation, and the second phase is idea organising. The last (intellectual) phase is achieved when learners have gone through group conflicts. These conflicts forced learners to learn to solve problems, and by the time they ended the conflicts, they would have increased their knowledge acquisition phase to the intellectual phase. The findings in this study have added to the theoretical knowledge of online learning. To make learners gain more than the content of the lesson, instructors need to add the element of group interaction with some twists of problem-solving activities.

\section{Pedagogical Implications and Suggestions for Future Research}

Instructors may consider providing more instruction and practise to students on non-verbal communication signals. Additionally, learners should be encouraged to share their knowledge and benefit from one another. This enables students to collaborate and work successfully in groups online. Instructors must actively design engaging and challenging group problemsolving activities that engage learners' interests. Learners may develop more independence if the instructor demonstrates trust and confidence in them, considering sufficient exercise provided through synchronous or asynchronous means. Instructors should encourage and educate learners properly to begin peer to peer online engagement and cooperation confidently.

It is recommended that future studies explore using qualitative techniques such as interviews to understand better learners' experiences and perceptions and the learning process in online collaborative learning. Additionally, the variables that contribute to the success of collaborative online education should be investigated to guarantee that courses are relevant and that learners are engaged online. 


\section{References}

Alias, A. A., Ab Manan, N. A., Yusof, J., \& Pandian, A. (2012). The use of Facebook as language learning strategy (LLS) training tool on college students' LLS use and academic writing performance. Procedia-Social and Behavioral Sciences, 67, 36-48. https://doi.org/10.1016/j.sbspro.2012.11.305

Anderson, T. (Ed.). (2008). The theory and practice of online learning. Athabasca University Press.

Aparicio, M., Bacao, F., \& Oliveira, T. (2016). An e-learning theoretical framework. An elearning theoretical framework, (1), 292-307. https://www.jstor.org/stable/jeductechsoci.19.1.292

Artino, A. R., \& Jones, K. D. (2012). Exploring the complex relations between achievement emotions and self-regulated learning behaviors in online learning. Internet and Higher Education, 15, 170-175. https://doi: 10.1016/j.iheduc.2012.01.006

Bączek, M., Zagańczyk-Bączek, M., Szpringer, M., Jaroszyński, A., \& Wożakowska-Kapłon, B. (2021). Students' perception of online learning during the COVID-19 pandemic: a survey study of Polish medical students. Medicine, 100(7). https://dx.doi.org/10.1097/MD.0000000000024821

Brindley, J. E., Blaschke, L. M., \& Walti, C. (2009). Creating effective collaborative learning groups in an online environment. International Review of Research in Open and Distributed Learning, 10(3). https://doi.org/10.19173/irrodl.v10i3.675

Barabasi, A. L. (2002). Linked: The new science of networks. Cambridge, MA: Perseus Publishing.

Cheng, E. W. L., \& Chu, S. K. W. (2015). Students' online collaborative intention for group projects: evidence from an extended version of the theory of planned behaviour. International Journal of Psychology, 51, 296-300. https://doi:10.1002/ ijop.12159

Chew, R. S. Y. (2015). Perceptions of online learning in an Australian University: Malaysian students' perspective-support for learning. International Journal of Information and Education Technology, 5(8). https://doi:10.7763/IJIET.2015.V5.573

Costley, J. (2021). How role-taking in a group-work setting affects the relationship between the amount of collaboration and germane cognitive load. Int J Educ Technol High Educ 18, 24. https://doi.org/10.1186/s41239-021-00259-w

Endut, A., Isa, P. M., Aziz, S. R. A., Jono, M. N. H. H., \& Aziz, A. A. (2012). e-Learning for Universiti Teknologi MARA Malaysia (UiTM): Campus wide implementation and accomplishments. Procedia-Social and Behavioral Sciences, 67, 26-35. https://doi.org/10.1016/j.sbspro.2012.11.304

Epignosis, L. L. C. (2014). E-learning concepts, trends, applications. California: Epignosis LLC, 5(6), 7.Retrieved from https://www.academia.edu/39950921/ELearning_Concepts_Trends_Applicationsi

Hamann, K., Pollock, P. H., \& Wilson, B. M. (2012). Assessing student perceptions of the benefits of discussions in small-group, large-class, and online learning contexts, college teaching, 60:2, 65-75. https:// doi: 10.1080/87567555.2011.633407

Hiltz, S. R., \& Turoff, M. (2005). Education goes digital: The evolution of online learning and the revolution in higher education. Communications of the ACM, 48(10), 59-64. https://doi.org/10.1145/1089107.1089139

Kamal, A. A., Shaipullah, N. M., Truna, L., Sabri, M., \& Junaini, S. N. (2020). Transitioning to online learning during COVID-19 Pandemic: Case study of a Pre-University Centre in 
Malaysia. International Journal of Advanced Computer Science and Applications, 11(6). https://doi:10.14569/IJACSA.2020.0110628

Kim, K. J., Liu, S., \& Bonk, C. J. (2005). Online MBA students' perceptions of online learning: Benefits, challenges, and suggestions. The Internet and Higher Education, 8(4), 335-344. https://doi.org/10.1016/j.iheduc.2005.09.005

Kumi-Yeboah, A., Dogbey, J., \& Yuan, G. (2017). Online collaborative learning activities: The perceptions of culturally diverse graduate students. Online Learning, 21(4), 5-28. https://doi:10.24059/olj.v21i4.1277

Koksal, I. (2020). The Rise Of Online Learning. Forbes.com. Retrieved from https://www.forbes.com/sites/ilkerkoksal/2020/05/02/the-rise-of-onlinelearning/?sh=5525fd0372f3

LaBeouf, J. P., Griffith, J. C., \& Roberts, D. L. (2016). Faculty and Student Issues with Group Work: What is problematic with college group assignments and Why? Journal of Education and Human Development, 13 - 23. https://doi.org/10.15640/jehd.v5n1a2

Le, H., Janssen, J., \& Wubbels, T. (2018) Collaborative learning practices: teacher and student perceived obstacles to effective student collaboration, Cambridge Journal of Education, 48:1, 103-122, DOI: 10.1080/0305764X.2016.1259389

Liang, R. Y. H., \& Chen, D. T. (2012). Online learning: Trends, potential and challenges. Scientific Research, 3(8), 1332-1335. http://dx.doi.org/10.4236/ce.2012.38195

Martin, F., \& Bolliger, D.U. (2018). Engagement matters: Student perceptions on the importance of engagement strategies in the online learning environment. Online Learning 22(1), 205- 222. doi:10.24059/olj.v22i1.1092

Messersmith A. S. (2015) Preparing students for 21st century teamwork: effective collaboration in the online group communication course, communication teacher, 29:4, 219-226. https:// doi: 10.1080/17404622.2015.1046188

Mulyono, H., Suryoputro, G., \& Jamil, S. R. (2021). The application of WhatsApp to support online learning during the COVID-19 pandemic in Indonesia. Heliyon, 7(8), e07853. https://doi.org/10.1016/j.heliyon.2021.e07853

Muuro, M., Wagacha, W., Kihoro, J., \& Oboko, R. (2014). Students' perceived challenges in an online collaborative learning environment: A case of Higher Learning Institutions in Nairobi, Kenya. International Review of Research in Open and Distributed Learning, 15(6), 132-161. https://doi.org/10.19173/irrodl.v15i6.1768

Nicholson, P. (2007). A history of e-learning. In Computers and education (pp. 1-11). Springer, Dordrecht.

Omodan, B. I., \& Ige. O. A. (2021). Sustaining collaborative learning among university students in the wake of covid-19: The perspective of online community project. International Journal of Learning, Teaching and Educational Research, 20 (1), 356-371. https://doi.org/10.26803/ijlter.20.1.20

Rahmat, N. H., Mok, S. S., Lau, S.K ., \& Ling, T. S. (2021) An Investigation of How Online Learning Reduces ZPD in Mandarin Language Classrooms. International Journal of Education, Vol 13(1), pp 1-15. Retrieved from https://doi.org/10.5296/ije.v13i1.18399

Robinson, K. (2013). The interrelationship of emotion and cognition when students undertake collaborative group work online: An interdisciplinary approach. Computers \& Education, 62, 298-307. https://doi:10.1016/j.compedu.2012.11.003

Roskosa, A., \& Rupniece, D. (2016). Advantages and drawbacks of using group work in translator training. Procedia - Social and Behavioral Sciences 231, 244-250. https:// doi:10.1016/j.sbspro.2016.09.098 
Sidek, E. A. R., \& Yunus, M. M. (2012). Students' experiences on using blog as learning journals. Procedia-Social and Behavioral Sciences, 67, 135-143. https://doi.org/10.1016/j.sbspro.2012.11.314

Tanjung, F. Z., \& Utomo, A. (2021). INVESTIGATING EFL STUDENTS' PERCEPTION ON ONLINE LEARNING AMIDST COVID-19 PANDEMIC. International Journal of Indonesian Education and Teaching (IJIET), 5(1), 102-115. https://doi.org/10.24071/ijiet.v5i1.3053.g2175

Trang, B. T. X., Nhi, H. Y., Uyen, N. T. B., Thanh, N. V. U., \& Thuy, N. T. C. (2021). A study on collaborative online learning among EFL students in Van Lang University (VLU). AsiaCALL Online Journal, 12 (3), 9-21. https://asiacall.info/acoj

Zakariah, Z., Alias, N., Abd Aziz, M. N., \& Ismail, N. Z. (2012). E-learning awareness in a higher learning institution in Malaysia. Procedia-Social and Behavioral Sciences, 67, 621-625. https://doi.org/10.1016/j.sbspro.2012.11.368 